\title{
TroyAcademy
}

International Journal of Social Sciences

\section{Üniversite Öğrencilerinde Uzaktan Eğitime Yönelik Tutumlar ile Akademik Öz-yeterlik Arasındaki İlişkiler ${ }^{1}$}

\author{
Araştırma Makalesi/ Research Article
}

Serda ÖZDİREK* Eyyüb Ensari CİCERALI'**

\section{ÖZET}

Araştırmanın amacı eğitim- öğretime uzaktan eğitim ile devam eden Çanakkale Onsekiz Mart Üniversitesi öğrencilerinin uzaktan eğitime yönelik tutumları ile akademik öz-yeterlik arasındaki bağı incelemektir. Araştırmada ilişkisel tarama yöntemi kullanılmıştır. Örneklem grubunu 331 öğrenci oluşturmuştur. Çalışmanın sonucunda akademik öz-yeterlik ile bölümü sevme değişkeni arasında anlamlı bir fark bulunurken uzaktan eğitimde öğrenci memnuniyeti ile anlamlı bir fark bulunmadığı, akademik öz-yeterlik ile memnuniyet puanlarının ANOVA varyans analizlerine göre akademik öz-yeterlik puanlarının da uzaktan eğitimde öğrenci memnuniyeti puanlarının da bilgisayar kullanım düzeyi değişkenine göre anlamlı bir farklılık gösterdiği tespit edilmiş̧ir. Memnuniyet puanlarının Akademik Öz-yeterlik puanlarını yordama düzeyini belirlemek için yapılan basit doğrusal regresyon analizlerine göre memnuniyet ve öz-yeterlik puanları arasında düşük düzeyde ve anlamlı bir ilişki bulunmuştur.

Anahtar Kelimeler: Akademik öz-yeterlik, Uzaktan ĕgitim, Uzaktan eğitim memnuniyeti, Uzaktan ĕgitime yönelik tutum, Üniversite ögrencileri

\section{Relations Between Distance Education Attitudes And Academic Self- Sufficiency In University Students}

\section{ABSTRACT}

The aim of the research is to examine the relationship between the attitudes of Çanakkale Onsekiz Mart University students, who continue their education with distance education, towards distance education and academic self-efficacy. Relational scanning method was used in the research. The sample group consisted of 331 students. As a result of the study, there was a significant difference between academic self-sufficiency and the variable of loving the department, while in distance education, student satisfaction there is no significant difference, academic self-sufficiency and satisfaction scores according to ANOVA variance analyses it has been found to differ significantly according to the computer usage level variable. Satisfaction according to simple linear regression analyses to determine the level of academic self-proficiency scores of satisfaction scores and low level of self- sufficiency scores and a meaningful relationship was found.

\footnotetext{
*Nişantaşı Üniversitesi, Lisansüstü Eğitim Enstitüsü, Psikoloji Yüksek Lisans Öğrencisi, serdaozdrk@gmail.com, ORCID ID: https://orcid.org/0000-0002-4094-5899

*** Dr.Öğr.Üyesi, Nişantaşı Üniversitesi, Psikoloji Ana Bilim Dalı, eyyub.cicerali@nisantasi.edu.tr, ORCID ID: https://orcid.org/0000-0001-5943-9972
} 
Keywords: Academic self-efficacy, Distance education, Distance education satisfaction, Attitude towards Distance Education, University Students

\section{GİRiș}

İnsanların içinde yaşadıkları ortamlara uyum sağlayabilmeleri, geçmişten bilgi ve tecrübeleri sonraki kuşaklara aktarabilmeleri ve bu temelde yaşadıkları döneme uygun yaşam tarzı geliştirmeleri gibi genel konularda ihtiyaç duydukları bilgi ve becerileri öğrenme yoluyla kazanırlar. Öğrenme yaşam boyu devam etmekte, bu süreci şekillendirmede eğitim kavramının önemine vurgu yapılmaktadır (Akkuş 2008: 12). Eğitim; kişilerin kendilerini geliştirmeleri, yeni beceriler kazanmaları ve kendilerinde olan bilgileri sürekli yenilemeleri gibi sistemlerin bütününe denir (Başaran, 1978: 18). Eğitim sürecinin etkili olmasında bireyin eğitim- öğretim ortamına ve konularına yönelik tutumları önemli etkiler yaratmaktadır. Öğrenenlerin eğitim süreçlerine olumlu tutumlar geliştirebilmeleri ise eğitimin, öğrencilerin ilgi ve gereksinimlerine uygun olarak düzenlenmesiyle ilişkilidir (Kaşarc1, Yiğit ve Yılmaz, 2012: 388). Çok eski zamanlarda mektupla başlayan iletişim kavramı daha sonra yerini pratik ve daha hızlı ulaşılabilir olan elektronik ortamda kurulan iletişime bırakır ve bu şekilde eğitimöğretim sistemi de her kuşak kendini şekillendirmek, geliştirmek durumunda kalır. Uzaktan iletişimin gelişmesiyle eğitim sisteminde de hem öğreticiler adına hem de öğrenenler adına daha ulaşılabilir olması için uzaktan eğitim sistemi oluşturulmuştur. Bu düzenlemede mevcut teknolojik olanakların eğitim ortamına katılması ve uzaktan sunulan hizmetlerle sorunlara daha hızlı müdahale edilebilmekte ve pratik çözümler üretilebilmektedir. Bu temelde yüz yüze eğitimin yapılamadığı durumlarda ya da eğitim süreçlerini desteklemek amacıyla geliştirilen uzaktan eğitim sistemleri ile zaman ve mekandan bağımsız öğrenme olanakları sunulabilmektedir (Kaya, 2002:18).

Uzaktan öğrenme süreci ile ilgili bağımsızlık ifadesini Wedemeyer ilk kez 1971'de kullanmıştır. Bağımsız öğrenmeyi çevrimiçi ortamda öğretme ve nasıl öğreneceğini kavramış kişi olarak tanımlar. Uzaktan eğitim üniversite, ilkokul, ortaokul öğrencileri, bedensel engeli olan öğrenciler olmak gibi her kesime hitap eder. Eğitimde kimilerine avantajlar sağlasa da kimilerine dezavantajlar sağlamaktadır (Anderson, 2007: 64). Uzaktan eğitimle beraber elektronik ortamda işlenen ders araç gereçlerine karş1 öğrencinin gösterdiği tutumlar öğrencinin kendisi ve öğreticiler tarafından bilinmesi, bu durumlara göre ders içeriklerinin ve tasarımlarının yapılması sanal ortamda öğrenmenin üzerinde durduğu önemli konulardan oluşur (Karaman ve Karabey, 2020: 12).

Tutum, bireyin çevresine karşı herhangi bir konuda edindiği deneyimler ve motivasyonlar bütününde kendinde oluşturduğu davranışsal, duygusal, ve bilişsel tepkiler eğilimidir (İnceoğlu, 2000). İnternet ortamında öğrenmenin BİT (Bilişsel İletişim Teknolojileri) ile gerçekleşmesi sebebiyle stres ve kaygı düzeyi teknoloji ile direkt olarak bağdaştırılmıştır (Spielberger, 1972: 388). Bilgisayar kullanımına 
karşı aşırı korku ve çekingen tavırlar, bilgisel teknolojilere karşı negatif tutum, teknolojik aletleri (tablet, telefon, bilgisayar gibi) kullanmaya çok az zaman ayırma veya bulundukları ortamı terk etmek isteme öğrencide teknolojiye yönelik bir kaygı olduğunu göstererek uzaktan eğitime karşı memnuniyetsizliğe yol açmaktadır. Bu da bize uzaktan eğitimin etkili şekilde gerçekleştirilmesinde kullanılan teknolojinin ne kadar ileri seviyede olduğu değil teknolojik aletleri kullananların uzaktan eğitime karşı ne kadar olumlu tutuma sahip olduğunun önemini vurgulamıştır (Liaw, 2007: 1080).

Uzaktan eğitimin öğrencilerde çoğunlukla gözlenen dezavantaj başlıkları motivasyon kaybı, ölçme ve değerlendirmenin olmaması, teknolojik kaynakların yetersizliği, teknik sorunlar, sosyalleşmede zayıflama, iletişim ve etkileşimde aksaklıklar, eğitimde fırsat eşitsizliğinin meydana gelmesi gibi durumlarla ilgilidir (Özdoğan ve Berkant, 2020: 43). Uzaktan eğitim öğrencilerde akademik anlamda motivasyon (güdülenme), özgüven, öz-yeterlik sorunlarla başa çıkabilme, planlama gibi kavramlarda olumlu/olumsuz etkiler yaratır. Akademik başarıyı da bireylerdeki öz-yeterlik algısı yönetir. Özyeterliği de güdülenme tetikler. Ve bu kavramlar zincirleme bir döngü oluşturur.

Öz-yeterlik kavramı bireylerin belli bir performansı göstermeleri için kendi kapasitelerine olan inançlarını ifade eder (Bandura, 1997: 167). Öz-yeterlik algısı ile bireylerin, aldıkları sorumlukları yerine getirip getirmeyecekleri belirlenir. Öz-yeterliği yüksek düzeyde olan bireyler, derslerde başarılı olacaklarına dair inançları da yüksek düzeyde olur ve bu sebepten ötürü olayları da iyi yönetebilmektedirler. Zorluklarla başa çıkma konusunda kendilerine güvendikleri için motivasyonları da yüksektir (Schuzlt ve Schuzlt, 2007: 89). Öz-yeterliği düşük bireyler ise sorumluluklarından çabuk sıkılıp sorumluluk aldıkları işi bir sonuca bağlamayıp pes ettikleri için hayal kırıklığına uğrarlar. Özyeterlik dış kaynaklarca gözlemlenebilen ve dış kaynaklarla etkileşimde olabilen bir özelliğe sahiptir (Lorsbach ve Jinks, 1999: 167). Bu sebepten ötürü öğrenmenin gerçekleştiği ortamların öğrencilerin öz-yeterlik algılarını yükseltici yönde geliştirilmesine uygun düzenlenmesi ve okudukları bölümlerde ders veren hocalarının tutumlarında, davranışlarında ve uyguladıkları öğretim izlenimlerinde öğrencilerin öz-yeterliklerini güçlendirici ifadeler benimsemeleri gerekmektedir (Sakız, 2013: 209). Öz-yeterliğin de kendi içinde alt dalları vardır. Bunlardan biri de akademik öz-yeterliktir.

Akademik öz-yeterlik öğrencilerin eğitim ile ilgili işlere yönelik yapabilirliklerine olan inancını ifade eder. Öğrencilerin öğrenme süreçlerini ve motive olmalarını tetikleyerek, zihinsel anlamda çaba harcamalarını sağlamaktadır. Güdülenme öğrenme için gerekli olan ilk şartlardan biridir ve kişinin davranışlarını harekete geçirerek yön vermesini sağlayan güçtür, enerjidir (Satıcı, 2013: 77). 


\section{KAVRAMSAL ÇERÇEVE}

Bu bölümde uzaktan eğitim kavramı, uzaktan eğitimin gelişimi, uzaktan eğitime yönelik tutumlar, uzaktan eğitimde memnuniyet, uzaktan eğitimde memnuniyeti etkileyen faktörler ile akademik özyeterlik kavramı ve akademik öz-yeterliği etkileyen faktörler ile ilgili kuramsal açıklamalara, konu ile ilgili hem yurt içinde hem de yurt dışında yapılmış olan araştırmalara yer verilmiştir.

\subsection{Uzaktan Eğitime Yönelik Tutumlar}

Günümüzde daha fazla kişinin öğrenim görmek istemesi, daha geniş kitlelere eğitim-öğretim hizmeti sağlanmanın amaçlanması, eğitim hayatında fırsat ve koşulların eşitliğini gerçekleştirebilme fikri çeşitli sebeplerden ötürü okula gelemeyen, öğrenim hayatına eksik devam eden öğrencilerin eğitim gereksinimlerinin karşılanması ve geleneksel eğitimden meydana gelen kaynakların sınırlılıklarını giderme mücadelesi uzaktan eğitim kavramının gerekliliğini gözler önüne sermektedir (Yalın, 2007: 345). Uzaktan eğitim kavramı ortaya çıktığından itibaren dezavantajları ve avantajlarıyla beraber üzerinde çok fazla değerlendirmeler yapılmıştır. Bilim insanları, öğrenciler ve öğretim üyeleri gibi akademik çatının altındaki her insanın münazara yapmasına açık bir konu olmuştur. Gerek teknolojik ortama uyum gerek uzaktan eğitim sisteminin geliştirilmesi için birden fazla çalışmalar yapılmıştır ve hala da yapılmaktadır. Öğrenciler eğitim alma konusunda problemler ve sınırlamalar yaşadıklarından dolayı uzaktan eğitimi tercih seçeneklerinin başına koymuşlardır. Bu sayede geniş öğrenci toplulukları uzaktan eğitim sisteminden faydalanmaya başlamıştır (Bayram vd., 2019: 345). Ancak uzaktan eğitim sürecinin gelişmesiyle bu sistemin dezavantajları da avantajları da daha net ortaya çıkmaktadır.

Uzaktan eğitim sisteminin dezavantajlarını şu şekilde sıralayabiliriz: Öğretim elemanlarının uzaktan eğitimde derse hazırlanırken çok fazla zaman harcamaları ve homeoffice çalışma tarzından dolayı iş yükünün evlere daha fazla taşınması dezavantaj olarak ifade edilmektedir. Hem üniversitede okuyup hem çalışan bireylerin işten geldikten sonra evde dinlenme olarak ayırdıkları zamanları derslerle geçirmektedir. Öğretim elemanlarının yaşları da uzaktan eğitim sistemine uyum sağlayabilme durumlarını etkilemektedir. Örneğin; yaşları ileri düzeyde olan kadın/erkek öğretmenlerin teknolojik aletleri kullanmada yaşadıkları eksiklik çevrimiçi eğitim ortamına alışabilmelerini zorlaştırmaktadır. Öğretmenlerdeki bilgisayar becerilerinin düşük düzeyde olması ders akışını etkileyerek öğrencilerin de uzaktan eğitimde kopukluklar yaşamasına yol açmaktadır. Yeni nesil öğretmenlerde ise teknolojiyle iç içe büyüdüklerinden dolayı bu sorun görülmemektedir (Horzum, 2003). Gelişen teknolojinin bölüm öğrencilerinin hayatında ve eğitim sisteminde de yerini alması, teknoloji ile yetişecek öğretmen adaylarının uzaktan eğitim sistemine yabancı olmayışları ve hayatlarında hem zaman hem mekân anlamında avantajlar sunmasının etkili olduğu ve yapılan çalışmaya paralellik gösterdiği söylenebilmektedir (Bayram vd., 2019: 335). Öğrencilerin ve öğretim elemanlarının bilgisayarda fazla 
süre geçirmeleri radyasyona sebep olarak, kansere yol açabilir. Bu yüzden ekranın başında uzun süre kalınmamalıdır. Teknik sorunlardan dolayı (internet ağının kopması, elektriklerin kesilmesi, ders için kullanılan teknolojik aletlerde güncellenme durumunun uzun sürmesi ya da ders için kullanılan teknolojik aletlerde arıza meydana gelmesi) dersin sağlıklı işlenmesine engel olmaktadır $\mathrm{Bu}$ durumun da öğrencilerde dikkat dağınıklığına ve odaklanma sorununa yol açması kaçınılmaz olacaktır. Öğrenci ve öğretim elemanlarının yüz yüze iletişimlerini kısıtlayarak, bireylerin sosyalleşmesini engellemektedir (Uşun, 2006: 75). Tüm bu nedenlerden dolayı öğrenciler uzaktan eğitime yönelik olumsuz tutum göstermektedir.

Uzaktan eğitim sisteminin avantajlarını şu şekilde sıralayabiliriz: Öğrencilerin mekana ve zamana bağlı kalmadan derslerini takip edebilme, çalışan bir bireye işi aksamadan eğitim hakkından yararlanabilme, öğrencilerin çevrimiçi platformlarda anlatılan konular üzerinde tekrar yapabilme ve öğrencilerin eksik kaldıkları konuları üniversitelerin sanal kampüsleri üzerinden tekrar açıp çalışabilme imkanı sunmaktadır (Bayram vd., 2019: 340). Maliyet konusunda örneğin; öğrencilerin okula giderken harcadıkları maliyet ve okulun içinde harcadıkları maliyet gibi firsatlar sağlamaktadır. Üniversitelerdeki öğretim elemanlarının okuldaki işlerini evlerine taşıyarak okulda ekstra zaman harcamamalarını sağlamaktadır. Öğrencilerin teknolojik ortamla iç içe olmasını sağlayarak teknolojik aletlerin kullanımının yaygınlaşmasını sağlar, bilgisayar kullanma becerisi kazandırır. Öğrencilere bağımsız bir çalışma ortamı sağlar (Kaya ve Önder 2002: 345). Dünyadaki tüm bilgilere internet aracılığıyla ulaşım sağlayarak öğrencilerdeki araştırmacı ruhun ön plana çıkmasına katkı ve esnek bir planlama sağlayarak günün ders dışı geri kalanında öğrencilerin kişisel gelişimleri için kendilerine vakit ayırabilmelerini sağlar (Ağır, 2007: 355). Uzaktan öğrenme ihtiyaçlarını zaman kelimesi ile ifade etmekte, yaşam boyu öğrenme ile sürekli artan bilgiye ulaşabilme süresinin uzaktan eğitim kavramı ile daha verimli kullanılabileceğinden söz etmektedir (Düzakın ve Yalçınkaya, 2008: 87). Tüm bu sebeplerden dolayı öğrenciler uzaktan eğitime yönelik olumlu tutum göstermektedir.

Topluluk duygusu öğrencilere öğreticiler tarafindan aşılanmalıdır (Palloff ve Pratt, 1999: 36). Eşzamanlı iletişimde öğreticiler ile öğrenenler monolog şeklinde değil diyalog şeklinde iletişim kurmalıdır. Sadece bilgi değil, duygu aktarımı yapılması gerekmektedir. Gerçek sınıf algısı yaratılmalıdır. Bunlar gerçekleştiği takdirde sağlıklı bir iletişim ortamı ve verimli bir öğrenme süreci sağlanmaktadır. Öğrencilerin yaşıtları, öğreticiler ve alanında uzman kişilerle iletişim bağı oluşturması ve bunu gerçek hayat vazifeleri içinde meydana getirmesi ile uzaktan eğitimi etkileyen bütün faktörleri pozitif düzeyde ise uzaktan eğitim sisteminde öğrenme kalıcı olarak gerçekleşebilir (Woo ve Reeves, 2007). Bu sebeple öğretim elemanları ve sınıf arkadaşları ile çevrimiçi ortamda ettiği sohbetler ve öğretim elemanları tarafından verilen ödevler online eğitimde öğrenci için önemli bir yere sahip 
olmaktadır. Online eğitimde öğretim elemanları tarafından verilen ödevler, öğrencilerin öğrenme sürecinde kendilerini keşfetmelerine yardımcı olur böylece 'uzaktan' da olsa desteklerinin var olduğunun farkına varırlar ve kendilerini uzaktan eğitim sisteminin bir parçası olarak hissetmeye başlarlar (Zimmerman ve Kitsantas, 2005: 96).

Uzaktan eğitimde internet tabanlı programlarda kullanılabilirlik önemli bir kavramdır ve uzaktan eğitime yönelik tutumu oldukça etkiler. Örneğin; sosyal buradalık öğrencilerin derse katılım ve motivasyonunu olumlu etkiler. Sosyal buradalık öğrenme topluluğundaki öğrencilerin uzaktan eğitim ortamında kendi kişisel düşüncelerini söyleyebilmesi ve diğer öğrencilerle iletişim kurabilme durumu olarak ifade edilir (Shea ve Bidjerano, 2009: 553). Çevrimiçi derslerin kalitesi, öğrenen desteği, öğrenme çıktıları, öğrenen etkileşimi, ders teknolojisi ve derse genel bakış maddeleri öğrencinin uzaktan eğitimde verim alabilmesi adına önem arz eder. Öğrenciler web sitesini, ders içerik platformlarını (örneğin; zoom, microsoft teams, üniversitelerin sanal kampüsleri) ne kadar doğru ve verimli kullanırlarsa, öğrenci ile web sitesi arasındaki bağ ne kadar iyi olursa öğrenmeleri de o düzeyde artacaktır (İşman, 2009: 65).

Çevrimiçi ortamda sınavlar da teknoloji sayesinde internet ortamında yapılmaktadır. Sınavlar üniversitelerin sanal kampüsleri üzerinden yapılır. Sınav sistemi örgün eğitimden farklıdır ve öğretim elemanları tarafından hazırlanması daha fazla zaman alır. Teknolojik ortama dayalı uzaktan eğitim daha kalabalık bir ekip çalışması ve teknik destek gerektirir. Internete dayalı uzaktan eğitimde sınavlarda farklı soru tarzları kullanmak mümkündür. Sınav sorularının bulunduğu ekranın modeli, yazı tipi, sayfa düzeni, görünümü ve renkleri öğrencinin dikkatini, motivasyonunu ve başarısını etkileyen faktörlerden biridir. Öğrencinin soruları çözerken odaklanmasında sorun oluşturabilecek gereksiz yazı stili, şekil, animasyon, simge gibi öğelerin ekranda bulunmamasına özen gösterilmelidir. Çevrimiçi ortamda gerçekleşen eğitimden verim alınabilmesi için öğretim elemanları ve öğrenciler ile birlikte uzaktan eğitim içinde bulunan herkes uzaktan eğitime olumluya odaklanma ile yaklaşmalıdır. (Tosun ve Hatipoğlu 2009: 289).

\subsection{Akademik Öz-yeterlik Kavramı}

Eskiden günümüze kadar akademik başarı kavramı bireylerin kendilerini geliştirebilmeleri ve iyi meslek kategorisi altında meslek edinebilmeleri adına önemli bir ölçütü oluşturmuştur. Hem toplumsal hem de bireysel açıdan okul başarısı oldukça önem taşımaktadır. Bu nedenle öğrencilerin akademik performansları, ergenlik zamanlarında yaşam doyumlarını ve psikososyal gelişimlerini etkileyebilmektedir (Steinmayr vd., 2016: 244). Akademik başarıyı da besleyen akademik öz-yeterlik olmuştur. Akademik öz-yeterlik, öğrencinin bireysel olarak öğrenim hayatı ile ilgili bir işi başarıyla sonuçlandırabileceğine yönelik kendinde var olan inancı olarak tanımlanmaktadır (Chun ve Choi, 
2005: 1169). İlkokul, ortaokul, lise ve üniversite olmak üzere eğitimin her yaş aralığında öğrenciler için gereklidir. Öğrencilerin güdülenmelerini sağlayarak onları harekete geçirir ve zihinlerini kullanmalarına teşvik eder. Akademik öz-yeterliği etkileyen değişkenler ve bu değişkenlerin akademik öz-yeterlik düzeyi üzerinde meydana getirdiği azalmalar/artmalar söz konusu olur. Akademik özyeterlik düzeyleri düştükçe öğrenciler kendilerine verilen ya da kendilerinin aldığı akademik görevlerden kaçmaktadırlar (Chemers, Hu ve Garcia, 2001; Kamin, 2009; Margolis ve McCabe, 2004 : 96). Zimmerman (1995: 96)'a göre akademik öz-yeterliğin en önemli özelliği öz-yeterlik inancının kişinin kişisel özelliklerini değil bir işi gerçekleştirme potansiyeli hususundaki yargılarını içerir. Özyeterlik düzeyleri çeşitli değişkenlere bağlıdır ve bu değişkenler ile belirlenir.

Akademik öz-yeterliği etkileyen birden fazla faktör vardır. Bunları her yaş aralığında olan öğrencilerin yaşadığı psikolojik ve duygusal durumları (mutluluk, umut, öfke, nefret, yaşanılan depresyon durumu, stres ve kaygı, yalnızlık hissi, motivasyon düzeyi, okulu ve bölümü sevme/sevmeme durumu) akademik başarısı, öz-saygısı, sınav kaygısı, okul terki, ergenlikte başlayıp yetişkinliğe kadar devam eden madde kullanımı, aile gelir durumu, bilgisayar kullanım becerisi, uyumu, doğum sırası, aile yapısı diye sıralamak mümkündür (Bandura, 1993: 46). Özellikle üniversite çağında olan öğrencilerin ebeveynlerinden, arkadaş çevrelerinden ya da öğreticilerden kendi kapasitelerine yönelik tehdit edici ve küçümseyici bir tavırla karşılaşmalarıyla beraber gelen kaygı yaratıcı durumlar öz-yeterlik üzerinde oldukça etkilidir (Pajares, 1996: 244).

Haycock ve arkadaşları düşük öz-yeterlik inancının ve yükssek kaygının erteleme davranışını tetiklediğini bulmuşlardır (Aydoğan ve Özbay, 2012). Akademik erteleme davranışı ve öz-yeterlilik inancı arasındaki ilişki incelendiğinde üniversite sınavına hazırlanan öğrencilerin çalışmalarında ve bu çalışmalarını sistematik halde sürdürebilmelerinde akademik öz-yeterlilik inancının önemi vurgulanmaktadır. Akademik öz-yeterlik inançları ile kişilik özellikleri, kontrol odağı ve akademik erteleme arasında ilişkiler tespit edilmiştir. Bazıları ilişkiler anlamlı kurulmuşken iken bazıları negatif yönde oluşmuştur (Albayrak, Yazıcı ve Reisoğlu, 2016: 102). Akademik öz-yeterlik de akademik başarıyı hem doğrudan hem de dolaylı olarak etkiler. Akademik başarı arttıkça akademik öz-yeterlik de artmaktadır. Bir öğrencinin mutluluk, iyimserlik ve umut gibi pozitif duyguları arttıkça kişinin akademik öz-yeterlik inancı da artmaktadır. Ancak öğrencinin kin, nefret, öfke gibi negatif duyguları arttıkça akademik öz-yeterlik inancı da ters orantılı olarak azalmaktadır. (Pajares, 1996: 244). Stres ve kaygının yoğun olduğu durumlarda da akademik öz-yeterliğin düştüğü görülmektedir (Torres ve Solberg, 2001: 96). Öğrencinin içinde bulunduğu depresyon durumu ve yalnızlık hissi kişide memnuniyetsizlik ve isteksizliğe yol açar. Bu durum kişinin iç dünyasını etkilediği gibi akademik faktörleri de etkileyerek kişinin akademik öz-yeterliğini düşürür (Poyrazlı vd., 2002: 244). Kişinin 
derslere yönelik motivasyon düzeyi yani eyleme ya da öğrenmeye geçme yönsemesi yüksek ise akademik öz-yeterliği de yükselmektedir. Ancak güdülenmesi, ders çalışma hevesi ve arzusu düşük ise akademik öz-yeterlik düzeyi bununla birlikte düşmektedir Okulu ve bölümü sevme değişkeninde akademik öz-yeterlik; öğrenci okuduğu bölümü ve devam ettiği okulu seviyorsa ilgisi de artmakta ve akademik öz-yeterliği de yükselmektedir, öğrenci okuduğu bölümü ve devam ettiği okulu sevmiyorsa ilgisi de azalmakta ve akademik öz-yeterliği de düşmektedir. Öğrencideki akademik çaba ve akademik planlama arttıkça akademik öz-yeterlik de artmaktadır (Zimmerman, Bandura ve MartinezPons, 1992: 96). Öğrencilerin ailelerinin gelir düzeyinin düşük/orta/yüksek olması ile öğrencilerin üniversite öğrenimleri bittikten sonra mesleki hayatlarında kazandıkları gelir düzeyi akademik öz-yeterliği büyük ölçüde etkilemektedir (Spinath, 2012: 244). Bir öğrenci içinde bulunduğu sınıf ortamına ve arkadaş grubuna uyum sağlarsa, adaptasyon sürecini başarılı bir şekilde gerçekleştirirse akademik öz-yeterliği de pozitif yönde etkileyerek arttırmaktadır (Poyrazli vd., 2002: 244). Özellikle ergenlik zamanında özyeterlik inancı gelişmemiş ya da oturmamış bireyler yetişkinliğe eriştiklerinde bu süreci daha zorlu geçirmektedir (Çubukçu ve Girmen, 2007: 13).

Öz-yeterlik ile ilgili ilk ifadeler, tanımlar ve yaklaşımlar Albert Bandura tarafından ortaya atılmıştır. Öz-yeterlik kavramı, sosyal öğrenme kuramında yer alan en önemli kavramlardan bir tanesidir (Saracaloğlu vd., : 385). Öz-yeterliğin alt türlerinden biri de akademik öz-yeterlik kavramıdır. Bandura (1997: 157)’ya göre öz-yeterlik kişinin deneyimleriyle şekillenen bir kavramdır. Değişkenlerine göre öz yeterlik inancı azalmaktadır/artmaktadır. Geçmiş hayatlarında sağlıklı ilişkiler kuran, başarılı işler gerçekleştiren ve psikolojik anlamda sağlıklı, mutlu olan kişilerin öz-yeterlik düzeyleri yüksek olurken, çevreleriyle kopuk ilişkiler kuran, psikolojik olarak çöküntüde olan umutsuz ve öfkeli, aldıkları sorumluluklardan kaçan, işlerini yarıda bırakan ve görevleri başarısızlıkla sonuçlandıran kişilerin ise öz-yeterlik düzeyleri düşmektedir. Sosyal Bilişsel Teori’ye göre kişilerin öz-yeterlik inançları kişinin hangi seçimleri nasıl yapacağı ve ne düzeyde gerçekleştireceği, engeller karşısında engelleri aşmak için ne kadar mücadele edeceği ve ne düzeyde kaygı, korku, heyecan yaşayacağı gibi birçok konuyu etkileyici etmen olarak görülür (Usher ve Pajares, 2008: 245).

\subsection{Uzaktan Eğitim ve Akademik Öz-yeterlik Arasındaki İlişkiler}

Dünyada eğitimi etkileyen çeşitli faktörler olduğu gibi uzaktan eğitimi etkileyen faktörler fazlaca vardır. Eğitimin kalitesi de bu faktörlere göre belirlenmekte ve şekillenmektedir. Eğitimde yüz yüze öğrenim görmenin yanı sıra mekana ve zamana bağlı kalmadan bilgiye daha hızlı ulaşılan uzaktan eğitim sistemi günümüzde daha da kullanımı yaygınlaşmış bir hal almaya devam etmektedir. Yüz yüze eğitimde olduğu gibi teknoloji ortamında gerçekleştirilen öğrenim tarzında da memnuniyet düzeyleri uzaktan eğitimi şekillendirmektedir (Bozkurt, 2017: 85). Öz-yeterlik düzeyleri öğrencilerin öğrenme 
güdülerinin üzerinde etkilidir. Öz-yeterlik düzeyi düşük öğrenciler öğrenmeye isteksizdir, öğreticilere ve ders içeriklerine yeterince odaklanamazlar, engelle karşılaştıklarında yüzleşmekten kaçınırlar veya bu zorlukların üstesinden gelmek için mücadele etmezler. Bu öğrencilerin uzaktan eğitim süreci boyunca akademik öz-yeterlik düzeyleri düşük olarak ilerlemektedir (Bandura, 1993: 40). Öğrenciler sorumluluklarını yerine getirmeye başladıkça, hem sosyal hayatında hem akademik hayatında kendisine duyduğu güven artar, özgüven arttıkça öz-yeterlik düzeyi artış göstermeye başlar.

Açımlayıcı faktör analizi yoluyla, çevrim içi öğrenme öz yeterliği beş boyut olarak belirlenmiş olup bunlardan biri uzaktan eğitimde akademik amaçlarla sınıf arkadaşlarıyla etkileşim kurmak için gerekli olan öz-yeterliktir (Shen, vd., 2013: 46). İnternet tabanlı ortamda gerçekleşen eğitimde öz-yeterlik kavramı, öğrencilerin uzaktan öğrenme ortamında bilgi, beceri, inanç ve tutumlarının şekillendirilmesini ve değiştirilmesini gerçekleştirmeye yönelik öz yeterlik inancı olarak tanımlamak mümkündür. Teknolojik ortamda gerçekleştirilen eğitim sisteminde bilgisayar kullanım becerisi düşük olan öğrenciler ile hiç bilmeyen öğrenciler, bunları kullanmaya ilişkin becerilerine daha az inanırlar. Kendilerinde var olan kapasitelerine inançları yani öz-yeterlik düzeyleri düşük olduğu için akademik öz-yeterlikleri de düşük olmaktadır. Kendilerinde var olan kapasitelerine inançları olduğu için de akademik öz-yeterlikleri yüksek olmaktadır (Nahm ve Resnick, 2008: 33).

\section{YÖNTEM}

\subsection{Araştırma Modeli}

Bu araştırma Çanakkale Onsekiz Mart Üniversitesi'nde okuyan öğrencilerinin uzaktan eğitime yönelik tutumlarla ilgili kuramsal yaklaşımlar ile akademik öz-yeterlik ve alt boyutlarının (akademik çaba, akademik planlama, akademik sorunlarla başa çıkma) arasındaki ilişkinin belirlenmesi amacıyla gerçekleştirilmiş olup ilişkisel tarama modeli kullanılmıştır. Bu nedenle akademik öz-yeterlik ölçeğinin alt boyutlarının gerçekleşme düzeyinin uzaktan eğitime yönelik tutumları ve sosyodemografik değişkenleri ne düzeyde etkilediğini belirlemek amacıyla regresyon analizi tekniği kullanılmıştır. Araştırması yapılan çalışma ilişkisel tarama modeline uygun olarak oluşturulmuştur. İlişkisel tarama modeli iki veya daha fazla değişkenin olduğu bir çalışmada değişkenler arasında ne gibi bir ilişkinin olduğunu ve birbirlerini etkileme düzeylerinin ölçüldüğü araştırma modeli olarak tanımlanmaktadır. Araştırmada veri toplamak amacıyla 30 sorudan oluşan Uzaktan Eğitimde Memnuniyet Ölçeği kullanılmıştır. Ölçek 7'li likert tipinde tasarlanmıştır. Toplanan veriler LISREL 8.72 istatistiksel analiz programı kullanılarak analiz edilmiş ve birinci sıralı doğrulayıcı faktör analizi yapılmıştır. İlk analiz sonunda RMSEA değeri 0.095 olarak bulunmuştur (Ilgaz, 2008). İkinci ölçek olarak 19 sorudan oluşan Akademik Öz-Yeterlik Ölçeği kullanılmıştır. Ölçek 5'li likert (hiç katılmıyorum, kısmen katılıyorum, katılıyorum, oldukça katılıyorum, tamamen katılıyorum) tipten ve 
akademik planlama, akademik sorunlarla başa çıkabilme ve alt boyutlarından meydana gelmiştir. Ölçek 320 öğrenceye uygulanarak gerçekleştirilmiştir. Cronbach alfa iç-tutarlılık katsayıları birinci faktör için .90, ikinci faktör için .78, üçüncü faktör için .77, ve ölçeğin bütünü için ise 92 olarak bulunmuştur. Her bir boyuta ilişkin madde toplam korelasyonları .36 ile .67 arasında değişmektedir (Kandemir, 2010).

\subsection{Evren ve Örneklem}

Araştırmanın evreni Çanakkale ilindeki eğitim-öğretime devam eden Çanakkale On Sekiz Mart Üniversitesi öğrencileri olarak belirlenmiş olup, araştırmada oransız eleman örnekleme yönteminden yararlanılarak en az 331 öğrenciden veri toplamak hedeflenmiştir.

Tablo 1. Araştırmaya Katılan Öğrencilere Sunulan Yedi Maddeli Kişisel Bilgi Formundan Elde Edilen Sonuçlar

\begin{tabular}{|c|c|c|c|c|c|}
\hline Değişken & & $F$ & $\%$ & $\%$ gec & $\%_{\text {yig }}$ \\
\hline \multirow[t]{2}{*}{ Cinsiyet } & Erkek & 181 & 54,7 & 54,7 & 54,7 \\
\hline & Kadın & 150 & 45,3 & 45,3 & 100,0 \\
\hline \multirow[t]{2}{*}{ Bölümü sevme } & Evet & 191 & 57,7 & 57,7 & 57,7 \\
\hline & Hayır & 140 & 42,3 & 42,3 & 100,0 \\
\hline \multirow[t]{2}{*}{ Üniversiteyi sevme } & Evet & 176 & 53,2 & 53,2 & 53,2 \\
\hline & Hayır & 155 & 46,8 & 46,8 & 100,0 \\
\hline \multirow[t]{3}{*}{ Aile gelir düzeyi } & Düşük & 52 & 15,7 & 15,7 & 15,7 \\
\hline & Orta & 144 & 43,5 & 43,5 & 59,2 \\
\hline & Yüksek & 135 & 40,8 & 40,8 & 100,0 \\
\hline \multirow[t]{3}{*}{ Anne eğitim düzeyi } & Ortaokul & 85 & 25,7 & 25,7 & 25,7 \\
\hline & Lise & 172 & 52,0 & 52,0 & 77,6 \\
\hline & Üniversite & 74 & 22,4 & 22,4 & 100,0 \\
\hline \multirow[t]{3}{*}{ Baba eğitim düzeyi } & Ortaokul & 73 & 22,1 & 22,1 & 22,1 \\
\hline & Lise & 164 & 49,5 & 49,5 & 71,6 \\
\hline & Üniversite & 94 & 28,4 & 28,4 & 100,0 \\
\hline \multirow{3}{*}{$\begin{array}{c}\text { Bilgisayar kullanım } \\
\text { düzeyi }\end{array}$} & Düşük & 85 & 25,7 & 25,7 & 25,7 \\
\hline & Orta & 115 & 34,7 & 34,7 & 60,4 \\
\hline & Yüksek & 131 & 39,6 & 39,6 & 100,0 \\
\hline
\end{tabular}

Tablo 1'de görüldüğü üzere çalışmaya katılan öğrencilerden elde edilen sonuçlara göre araştırmanın örneklem grubunun 150'si (\%45,3) kadın; 181’i (\%54,7) erkek iken, $191(\% 57,7)$ kişi okuduğu bölümü severken $140(\% 42,3)$ kişi okuduğu bölümü sevmemektedir. Ayrıca $176(\% 53,2)$ kişi okuduğu 
üniversiteyi severken 155'i (\%46,8) sevmemektedir. 52 (\%15,7) kişi gelir düzeyini düşük, 144 $(\% 43,5)$ kişi orta ve $135(\% 40,8)$ kişi yüksek olarak belirtmiştir. 85 (\%25,7) kişinin anne eğitim düzeyi ortaokul, 172'nin (\%52) lise ve 74'nün $(\% 22,4)$ üniversitedir. Kat1lımc1ların baba eğitim düzeylerine bakıldığ1 zaman 73'nün $(\% 22,1)$ ortaokul, 164'nün $(\% 49,5)$ lise ve 94'nün $(\% 28,4)$ ise üniversite mezunu olduğu görülmektedir. Son olarak katılımcıların bilgisayar kullanım düzeyi oranları 85'i $(\% 25,7)$ düşük, 115'1 $(\% 34,7)$ orta ve 131'i $(\% 39,6)$ ise yüksek olarak tespit edilmiştir.

\subsection{Veri Toplama Araçları ve Analiz Yöntemi}

Katılımcıların sosyodemografik özellikleri ve öz yeterlik, akademik planlama, akademik başarı düzeylerine ilişkin bilgiler almak amacıyla Kişisel Bilgi Formu, uzaktan eğitime yönelik tutumlar ile ilgili veriler "Uzaktan Eğitimde Öğrenci Memnuniyeti Ölçeği”, derslere yönelik akademik öz-yeterlik ile ilgili veriler “Akademik Öz-Yeterlik Ölçeği” ile toplanmıştır. Kişisel bilgi formu ve ölçeklerin anket soruları Google Form'da hazırlanmıştır. Uygulamaya, araştırmacı tarafından internet üzerinden link gönderilerek katılımcıların katılması sağlanmıştır. Katılımcılara gerekli bilgiler verilerek, anket verilerinin katılımcıların kişisel bilgileri (ad- soyad) gizli kalacak şekilde ve gönüllülük esasına dayanarak uygulanacağı bildirilmiştir. Uygulama esnasında katılımcılara zaman kısıtlaması yapılmamıştır. Araştırmada elde edilen veriler SPSS 22.0 analiz programı kullanılarak çözümlenmiştir. Analiz yapılırken değişkenler arası ilişkiler için çarpım moment korelasyon analizi, iki gruplu karşılaştırmalar için bağımsız gruplar t testi, ikili değişkenleri değerlendirmek için tek yönlü varyans analizi Anova testi kullanılmıştır, gruplar arasında anlamlı bir farklılık olduğunu/olmadığını görmek için post-hoc testlerinden yararlanılmıştır ve yordayıcı etkiler için basit doğrusal regresyon analizi uygulanmıştır.

\section{BULGULAR}

\subsection{Değişkenler Arasındaki İlişkilere Yönelik Korelasyon Analizi Bulguları}

Tablo 2. Değişkenler Arasındaki İlişkiyi Belirlemek Üzere Yapılan Pearson Çarpım Moment Korelasyon Analizi Sonuçları

\begin{tabular}{|c|c|c|c|c|c|}
\hline Değişkenler & Memnuniyet & Çaba & $\begin{array}{l}\text { Sorunlarla } \\
\text { başa çıkma }\end{array}$ & Planlama & Öz-yeterlik \\
\hline Memnuniyet & 1 & & & & \\
\hline Çaba &, $113^{*}$ & 1 & & & \\
\hline Sorunlarla başa çıkma &, $154^{* *}$ &, $498^{* *}$ & 1 & & \\
\hline Planlama &, $160^{* *}$ &, $532^{* *}$ &, $649^{* *}$ & 1 & \\
\hline
\end{tabular}




\begin{tabular}{|c|c|c|c|c|c|}
\hline Öz-yeterlik &, $168^{* *}$ &, $737^{* *}$ &, $912^{* *}$ &, $836^{* *}$ & 1 \\
\hline
\end{tabular}

Tablo 2'de görüldüğü üzere hem değişkenler arasındaki ilişkiyi belirlemek üzere Pearson korelasyon analizleri gerçekleştirilmiştir. Uzaktan Eğitimde Öğrenci Memnuniyeti ölçeği Akademik Öz yeterlik Ölçeği puanları arasında $(\mathrm{r}=, 168)$ pozitif yönde ve düşük düzeyde anlamlı bir ilişki olduğu görülmektedir $(\mathrm{p}<.01)$. Ayrıca Akademik Öz yeterlik Ölçeği alt boyutlarından çaba $(\mathrm{r}=., 113)$, sorunlarla başa çıkma $(\mathrm{r}=, 154)$ ve planlama $(, 160)$ puanları arasında da pozitif yönde ve düşük düzeyde anlamlı bir ilişki olduğu görülmektedir.

\subsection{Betimleyici İstatistik Değerler}

Tablo 3. Akademik Öz-Yeterlik Ölçeği Puanları İçin Betimleyici İstatistik Değerleri

\begin{tabular}{|c|c|c|c|c|c|c|c|c|}
\hline Boyutlar & $\mathbf{N}$ & $\mathbf{M i n}$ & Maks. & $\overline{\mathbf{x}}$ & $\mathbf{S h}_{\mathbf{x}}$ & $\mathbf{\text { SS }}$ & Çarpık. & Basık. \\
\hline Çaba & 331 & 6,00 & 24,00 & 16,5468 &, 15249 & 2,77435 &,- 811 & 1,063 \\
\hline Planlama & 331 & 6,00 & 26,00 & 21,5408 &, 16661 & 3,03125 & $-1,110$ & 1,062 \\
\hline $\begin{array}{c}\text { Sorunlarla başa } \\
\text { çıkma }\end{array}$ & 331 & 23,00 & 50,00 & 41,9094 &, 28697 & 5,22096 &,- 575 &, 247 \\
\hline Öz-yeterlik & 331 & 35,00 & 95,00 & 79,8822 &, 51645 & 9,39607 &,- 700 & 1,031 \\
\hline
\end{tabular}

Kaynak: Tabachnick and Fidell, 2013 B.G. Tabachnick, L.S. Fidell Using Multivariate Statistics (sixth ed.)Pearson, Boston (2013)

Tablo 3'te görüldüğü üzere Hem Akademik Öz-Yeterlik Ölçeği toplam puanının hem de alt boyutlarının çarpıklık ve basıklık değerlerine baktığımızda ölçekten alınan puanların çarpıklık ve basıklık değerlerinin 1,5 ve -1,5 aralığında olduğu ve normal bir dağılım gösterdiği görülmektedir.

Tablo 4: Memnuniyet Ölçeği Puanları İçin Betimleyici İstatistik Değerleri

\begin{tabular}{|c|c|c|c|c|c|c|c|c|}
\hline Boyutlar & $\mathbf{N}$ & Min & Maks. & $\overline{\mathbf{x}}$ & $\mathbf{S h}_{\mathbf{x}}$ & ss & Çarpık. & Basık. \\
\hline Memnuniyet & 331 & 102,00 & 209,00 & 164,4018 & 1,39055 & 25,29891 &,- 253 &,- 593 \\
\hline
\end{tabular}

Kaynak: Tabachnick and Fidell, 2013 B.G. Tabachnick, L.S. Fidell Using Multivariate Statistics (sixth ed.)Pearson, Boston (2013)

Tablo 4'te görüldüğü üzere Memnuniyet Ölçeği puanının çarpıklık ve basıklık değerlerine baktığımızda ölçekten alınan puanların çarpıklık ve basıklık değerlerinin 1,5 ve -1,5 aralığında olduğu ve normal bir dağılım gösterdiği görülmektedir. 


\subsection{Tek Yönlü Varyans Analizi Sonuçları}

Tablo 5. Akademik Öz-Yeterlik Ölçeği Ve Memnuniyet Ölçeği Puanlarının Bilgisayar Kullanım Düzeyi Değişkenine Göre Farklılaşıp Farklılaşmadığını Belirlemek Üzere Yapılan Tek Yönlü Varyans Analizi ANOVA Testi Sonuçları

\begin{tabular}{|c|c|c|c|c|c|c|c|c|c|c|}
\hline Ölçek & Gruplar & $\mathbf{N}$ & $\overline{\mathrm{x}}$ & Ss & Var.K. & $K T$ & $S d$ & KO & $F$ & $P$ \\
\hline \multirow{3}{*}{ Memnuniyet } & Düşük & 85 & $\begin{array}{c}153,0 \\
471\end{array}$ & $\begin{array}{c}26,83 \\
987\end{array}$ & G.aras1 & $\begin{array}{c}16085,1 \\
53\end{array}$ & 2 & $\begin{array}{c}8042, \\
577\end{array}$ & $\begin{array}{l}13, \\
519\end{array}$ & $\begin{array}{c}00 \\
0\end{array}$ \\
\hline & Orta & 115 & $\begin{array}{c}165,8 \\
348\end{array}$ & $\begin{array}{c}24,28 \\
050\end{array}$ & G.içi & & 328 & $\begin{array}{c}594,8 \\
98\end{array}$ & & \\
\hline & Yüksek & 131 & $\begin{array}{c}170,5 \\
115\end{array}$ & $\begin{array}{c}22,77 \\
089\end{array}$ & Toplam & & 330 & & & \\
\hline \multirow{3}{*}{ Öz-yeterlik } & Düşük & 85 & $\begin{array}{c}73,05 \\
88\end{array}$ & $\begin{array}{c}10,13 \\
522\end{array}$ & G.aras1 & $\begin{array}{c}9482,31 \\
1\end{array}$ & 2 & $\begin{array}{c}4741, \\
156\end{array}$ & $\begin{array}{l}79, \\
131\end{array}$ & $\begin{array}{c}, 00 \\
0\end{array}$ \\
\hline & Orta & 115 & $\begin{array}{c}77,85 \\
22\end{array}$ & $\begin{array}{c}7,372 \\
59\end{array}$ & G.içi & $\begin{array}{c}19652,0 \\
94\end{array}$ & 328 & $\begin{array}{c}59,91 \\
5\end{array}$ & & \\
\hline & Yüksek & 131 & $\begin{array}{c}86,09 \\
16\end{array}$ & $\begin{array}{c}6,093 \\
44\end{array}$ & Toplam & $\begin{array}{c}29134,4 \\
05\end{array}$ & 330 & & & \\
\hline
\end{tabular}

Tablo 5'te görüldüğü üzere Akademik Öz yeterlik ve Memnuniyet Ölçeği puanlarının bilgisayar kullanım düzeyi değişkenine göre anlamlı bir farklılık gösterip göstermediğini belirlemek amacıyla gerçekleştirilen tek yönlü varyans analizi (ANOVA) sonucunda hem Akademik Öz yeterlik Ölçeği puanlarının $\quad\left(\mathrm{F}_{(2,328)}=13,55 ; \mathrm{p}<.05\right) \quad$ hem de Memnuniyet Ölçeği puanlarının $\left(\mathrm{F}_{(2,328)}=, 733 ; \mathrm{p}<.05\right)$ bilgisayar kullanım düzeyi değişkenine göre istatiksel açıdan anlamlı bir farkl111k göstermektedir $\left(\mathrm{F}_{(2,328)}=, 79,1 ; \mathrm{p}<.05\right)$.

Tablo 6. Akademik Öz-Yeterlik Ölçeği Ve Memnuniyet Ölçeği Puanlarının Anne Eğitim Düzeyi Değişkenine Göre Yapılan Tek Yönlü Varyans Analizi ANOVA Testi Sonuçları

\begin{tabular}{|c|c|c|c|c|c|c|c|c|c|c|}
\hline Ölçek & Gruplar & $\mathbf{N}$ & $\overline{\mathrm{x}}$ & Ss & Var.K. & $K T$ & $S d$ & KO & $F$ & $P$ \\
\hline \multirow{3}{*}{ Memnuniyet } & Ortaokul & 85 & $\begin{array}{c}163,9 \\
882\end{array}$ & $\begin{array}{c}24,62 \\
601\end{array}$ & G.aras1 & $\begin{array}{c}223,3 \\
79\end{array}$ & 2 & $\begin{array}{c}111,6 \\
90\end{array}$ & $\begin{array}{c}, 17 \\
4\end{array}$ & $\begin{array}{c}, 84 \\
1\end{array}$ \\
\hline & Lise & 172 & $\begin{array}{c}163,9 \\
477\end{array}$ & $\begin{array}{c}25,74 \\
919\end{array}$ & G.içi & $\begin{array}{c}21098 \\
8\end{array}$ & 328 & $\begin{array}{c}643,2 \\
57\end{array}$ & & \\
\hline & Üniversite & 74 & $\begin{array}{c}165,9 \\
324\end{array}$ & $\begin{array}{c}25,28 \\
486\end{array}$ & Toplam & $\begin{array}{c}21121 \\
1\end{array}$ & 330 & & & \\
\hline
\end{tabular}




\begin{tabular}{|c|c|c|c|c|c|c|c|c|c|c|}
\hline & Ortaokul & 85 & $\begin{array}{c}75,30 \\
59\end{array}$ & $\begin{array}{c}9,773 \\
66\end{array}$ & G.arasi & $\begin{array}{c}4483, \\
491\end{array}$ & 2 & $\begin{array}{c}2241, \\
745\end{array}$ & $\begin{array}{c}29, \\
828\end{array}$ & $\begin{array}{c}, 00 \\
0\end{array}$ \\
\cline { 2 - 10 } Öz-yeterlik & Lise & 172 & $\begin{array}{c}79,55 \\
23\end{array}$ & $\begin{array}{c}8,559 \\
57\end{array}$ & G.içi & $\begin{array}{c}24650 \\
, 914\end{array}$ & 328 & 75,15 & & \\
& Üniversite & 74 & $\begin{array}{c}85,90 \\
54\end{array}$ & $\begin{array}{c}7,492 \\
77\end{array}$ & Toplam & $\begin{array}{c}29134 \\
, 405\end{array}$ & 330 & & & \\
\cline { 2 - 11 } & & & & & & & \\
\hline
\end{tabular}

Tablo 6'da görüldüğü üzere Akademik Öz yeterlik ve Memnuniyet Ölçeği puanlarının anne eğitim düzeyi değişkenine göre anlamlı bir farklılık gösterip göstermediğini belirlemek amaciyla gerçekleştirilen tek yönlü varyans analizi (ANOVA) sonucunda sadece Akademik Öz yeterlik Ölçeği puanlarının anne eğitim düzeyi değişkenine göre istatiksel açıdan anlamlı bir farklılık gösterdiği görülürken $\left(\mathrm{F}_{(2,328)}=, 174 ; \mathrm{p}<.05\right)$, Memnuniyet Ölçeği puanlarının anne eğitim düzeyi değişkenine göre istatiksel açıdan anlamlı bir farklılık göstermediği tespit edilmiştir. $\left(\mathrm{F}_{(2,328)}=29,828 ; \mathrm{p}>.05\right)$. Akademik Öz yeterlik Ölçeği puanlardaki bu anlamlı farklılı̆̆ın hangi gruplar arasında farklılaştığını belirlemek üzere tamamlayıcı post-hoc analiz tekniklerine geçilmiştir. Hangi post-hoc çoklu karşılaştırma tekniğinin kullanılacağına karar vermek için öncelikle Levene's testi ile grup dağılımlarının varyanslarının homojen olup olmadığı hipotezi sınanmış, grup varyansların homojen olduğu görülmüştür $(\mathrm{p}>.05)$. Bu yüzden varyansların homojen olduğu durumlarda kullanılan Tukey çoklu karşılaştırma tekniği tercih edilmiştir. Gerçekleştirilen tamamlayıcı analiz sonuçları aşağıdaki tabloda sunulmuştur.

\subsection{Doğrusal Regresyon Analizine Yönelik Bulgular}

Tablo 7. Memnuniyet Ölçeği Puanının Akademik Öz-Yeterlik Öıçeği Puanlarını Yordama Düzeyine İlişkin Basit Doğrusal Regresyon Analizi Sonuçları

\begin{tabular}{|c|c|c|c|c|c|}
\hline Değişken & B & SH. & B & T & P \\
\hline Sabit & 69,36 & 3,358 & & 20,741 &, 00 \\
\hline Memnuniyet &, 062 &, 020 &, 210 & 3,810 &, 00 \\
\hline
\end{tabular}

Tablo 7'de görüldüğü üzere Memnuniyet Ölçeği puanının Akademik Öz yeterlik Ölçeği puanlarını yordama düzeyini belirlemek için yapılan basit doğrusal regresyon analizi sonuçlarına göre memnuniyet ve öz-yeterlik puanları arasında düşük düzeyde ve anlamlı bir ilişki bulunmaktadır. Memnuniyet Ölçeği öğrenci adaylarının Akademik Öz yeterlik puanlarındaki varyansın \% 2,8'ini açıkladığı görülmektedir $\left(\mathrm{R}=, 168 \mathrm{R}^{2}=, 028 \mathrm{~F}(1,329)=9,57, \mathrm{p}<.001\right)$. 


\section{SONUÇ VE TARTIŞMA}

Araştırmada uzaktan eğitime yönelik tutumların akademik öz-yeterlik üzerindeki etkileri ve bazı değişkenler ile aralarındaki ilişki; uzaktan eğitime yönelik tutumlar ile bazı değişkenler arasındaki ilişki ve üniversite öğrencilerinin uzaktan eğitime yönelik tutumlarının akademik öz-yeterliklerini ne düzeyde yordadığına ilişkin sonuçların yorumlarına yer verilmiştir. Yapılan çalışmanın sonucunda akademik öz-yeterlik ile uzaktan eğitimde öğrenci memnuniyeti ölçeği ve cinsiyet değişkeni arasında anlamlı bir fark bulunmamıştır. Literatüre bakıldığı zaman bu çalışmanın sonuçları ile paralel çalışmalar mevcuttur. Oğuz (2009), Choi (2005), Taşkın ve Hacıömeroğlu (2010), Usher ve Pajares (2006) 'in yaptığı çalışmalarda da cinsiyet ve Akademik Öz-Yeterlik ile Memnuniyet Ölçeği puanları arasında anlamlı bir farkın olmadığı görülmektedir. Ancak Block ve Robins (1993), Marayam, Ghasemzadeh ve Soleimani (2011)'in yaptığı çalışmada cinsiyet ile öz- yeterlik konusunda anlamlı bir farkın olduğu görülmektedir. Toplumumuzda eskiden beri kadın bireylerin cinsiyetlerinden dolayı erkek egemen anlayışı ve üstünlüğü ile toplum içinde baskıya maruz kaldıkları ve yaşamları boyunca davranışlarının bastırıldığı ve yönlendirildiği yadsınamaz bir gerçektir. $\mathrm{Bu}$ da kadınların doğduklarından beri erkeklere göre daha çekingen ve özgüveni düşük bireyler olmasına sebep olmaktadır (Aktaş, 2013: 55).

Akademik öz-yeterlik ile bölümünü sevme değişkeni arasında anlamlı bir fark bulunurken uzaktan eğitimde öğrenci memnuniyeti ölçeği puanları ile anlamlı bir fark bulunmadığı tespit edilmiştir. Literatür incelendiğinde bu durumu destekleyen çalışmalar olduğu görülmüştür. Yapıcı ve Yapıcı (2013: 1393)'ya göre Öğretmenlik bölümü okuyan öğrencilerin bölümlerine yönelik olarak genellikle bölümlerini severek olumlu bir tutuma sahip oldukları görülmektedir. Ancak Dündar ve Karaca (2013: 1393)'nın araştırmalarına göre öğrencilerin okudukları bölüme yönelik olarak olumsuz bir tutuma sahip olduklarını gösteren çalışmalar da görülmektedir. Okuduğu bölümü seven öğrencilerin özyeterlik düzeyleri de yüksek olmaktadır. Uzaktan eğitim sisteminde ağırlıklı olarak sözel dersler işlenen (psikoloji, edebiyat, hukuk, sosyoloji gibi) bölümlerde okuyan üniversite öğrencileri, sayısal alanda (eczacılık, tıp, tıbbi teknikerlik gibi laboratuvar ortamında ders görenler) okuyan öğrencilere ya da uygulamalı dersleri (mimarlık, grafik tasarım gibi) daha ağırlıklı olan bölümlerde okuyan öğrencilere göre bölümlerine/derslerine daha çok adapte olacakları düşünülebilir (Şenel ve Kutlu, 2015: 178).

Akademik öz-yeterlik ile üniversiteyi sevme değişkeni arasında anlamlı bir fark bulunurken uzaktan eğitimde öğrenci memnuniyeti ölçeği puanları ile anlamlı bir fark bulunmadığı tespit edilmiştir. Literatüre bakıldığı zaman bu durumu destekleyen çalışmaların olduğu görülmüştür. Özgenel ve Deniz (2020: 138) 'in araştırmasından elde edilen sonuçlara göre eğitim fakültesi öğrencilerinin bölüme ve 
okudukları üniversiteye karşı olumlu tutum sergilemesi, mesleklerine yönelik bağl1lık göstermesi ile ilişkilendirilebilir. Öğrencilerin üniversitelerinin fakültelerine karşı akademik öz-yeterlik düzeylerinin yüksek olması okullarındaki eğitim- öğretim faaliyetlerinin kalitesini arttırabilir. Genel bulgulara göre öğrencilerinin mesleklerine yönelik tutumları ile akademik güdülenmelerinin akademik özyeterliklerini anlamlı düzeyde yordadığı sonucuna varılmıştır (Seki vd.; 2018: 168). Uzaktan eğitimde öğrenci memnuniyeti ölçeği puanları ile üniversiteyi sevme kısmı arasında anlamlı bir fark bulunmamıştır. Literatüre bakıldığı zaman bu konuyla ilgili kesin bir sonuca varan çalışmalar olmamakla birlikte çalışmalardan elde edilen ortak sonuca göre online ortamda gerçekleştirilen eğitimde kaynakların yetersiz olması, internet ağındaki teknik sorunlar, teknolojik ortama ulaşamama gibi durumlar uzaktan eğitime yönelik olumsuz tutum gösterilmesine sebep olmaktadır. Uzaktan öğrenim sürecini sağlıklı yönetemeyen bir üniversiteye karşı öğrenciler olumsuz tutum sergileyebilir ve buna paralel olarak da memnuniyetsizlik söz konusu olabilir (Özdoğan ve Berkant, 2020: 16).

Akademik öz-yeterlik ile aile gelir düzeyi değişkeni arasında anlamlı bir fark bulunurken uzaktan eğitimde öğrenci memnuniyeti ölçeği puanları ile anlamlı bir fark bulunmadığı tespit edilmiştir. Gelir düzeyi düşük olan aileler gelir düzeyi yüksek olan ailelere göre çocukları adına eğitimin sunduğu olanaklara daha geç ulaşmaktadır ya da kısıtlı bir şekilde ulaşmak zorunda kalmaktadır (Önür, 2013: 263).

Akademik öz-yeterlik ile anne eğitim düzeyi değişkeni arasında anlamlı bir fark bulunurken uzaktan eğitimde öğrenci memnuniyeti ölçeği puanları ile anlamlı bir fark bulunmadığı tespit edilmiştir. Literatür incelendiğinde buna paralel çalışmaların olduğu görülmektedir. Özgüven (1974: 267)'in araştırmasının sonuçlarına göre öğrencilerin başarılarında ve öz- yeterliklerinde aileleriyle olan ilişkileri etkili faktörlerden biridir.

Akademik öz-yeterlik ile baba eğitim düzeyi değişkeni arasında anlamlı bir fark bulunurken uzaktan eğitimde öğrenci memnuniyeti ölçeği puanları ile anlamlı bir fark bulunmadığı tespit edilmiştir. Literatüre bakıldığı zaman bu çalışmayı destekleyecek araştırmaların olduğu görülmektedir. Karaduman (2015)'in çalışmasının sonucuna göre öğrencilerin babalarının daha çok ticari içerikler ve sayısal hesaplamalar bulunduran muhasebeci gibi meslekler olanların, iktisadi idari bilimler fakültesi ya da ticaret meslek lisesi gibi ticari matematik gerektiren alanlardan mezun olanların akademik özyeterlikleri daha yüksek olduğu tespit edilmiştir. Baba eğitim durumunun öğrencinin akademik özyeterlik düzeyinin belirlenmesinde anne eğitim durumunda ifade ettiğimiz gibi ikili ilişkilerin olumlu olması çocuğu mutlu eder, mutlu olan çocuk da kendine güven duymaya başlar bu durum özgüveni tetiklediği gibi akademik başarının ve öz-yeterlik düzeyinin yükselmesini de tetikler diyebiliriz (Ummanel, 2010: 207). Akademik öz-yeterlik ile memnuniyet ölçeği puanlarının hem akademik öz- 
yeterlik ölçeği puanlarının hem de uzaktan eğitimde öğrenci memnuniyeti ölçeği puanlarının bilgisayar kullanım düzeyi değişkenine göre anlamlı bir farklılık gösterdiği tespit edilmiştir. Literatür incelendiğinde bu sonucu destekleyen başka çalışmaların mevcut olduğu görülmektedir. Çağır (2010: 90)' un araştırmalarına göre üniversiteye yeni başlayan öğrencilerin internet kullanımında zorlanmaması, üniversite hayatı ile birlikte değişen ihtiyaçlar ve yeni sosyal ortama ayak uydurma ile zengin bir sosyal çevre oluşturabilmek için arkadaşlarla daha çok zaman geçirme çabası sayesinde olabilir. Sonuç olarak teknolojik aletleri kullanım becerisi yüksek olan öğrencilerin uzaktan eğitimde derslerde ve sınavlarda daha iyi sonuçlar elde ettiği, teknolojik aletleri kullanım becerisi düşük olan öğrencilerin ise daha kötü sonuçlar elde ettiğini söylemek yanlış olmayacaktır (Özdoğan ve Berkant, 2020: 32).

Uzaktan eğitime yönelik tutumlar ile akademik öz-yeterlik arasındaki ilişki anlamlı düzeyde yordanmaktadır. Uzaktan eğitimde üniversite öğrencileri bilgi akışına hızlı ulaşabildikleri için bu sistem onların memnuniyet düzeylerini yükseltse de birçok değişkenin etkisiyle memnuniyet algılarını olumlu/olumsuz olarak fazlasıyla etkilemektedir. Bilgiye çabuk ve zamana/mekana bağlı kalmadan istenilen zamanda ulaşabilme uzaktan eğitim sisteminde öğrenenler ve öğreticiler için avantajlı bir durum olmaktadır (Varol; akt. Çoban, 2013: 94). Bir uzaktan eğitim sisteminde var olması gereken üç önemli öge vardır. Bunlardan birincisi öğrencidir, ikincisi iletişim ortamıdır ve üçüncüsü de kaynaklardır (Alkan, 1987: 14). Bunlar eksiksiz ve doğru bir şekilde yerine getirildiğinde uzaktan eğitime yönelik öğrenci memnuniyeti sağlanır. Genel olarak değerlendirildiğinde sonuç olarak uzaktan eğitime yönelik tutumlar ile akademik öz-yeterlik arasında anlamlı bir ilişki bulunmaktadır (Etlioğlu ve Tekin, 2020: 48).

\section{SINIRLILIKLAR VE ÖNERILER}

Öğrencilerin akademik öz-yeterliğinin ve uzaktan eğitime yönelik tutumlarının yüksek düzeyde olabilmesi için aile gelir düzeyi, anne baba eğitim durumu, okulu ve bölümü sevme, bilgisayar eğitim düzeyi, cinsiyet gibi değişkenlerin olumlu yanlarını yüksek seviyeye çıkarıp olumsuz yanlarını ortadan kaldırmak gerekir. Araştırmadaki değişkenler genişletilip yaş, medeni durum ve kardeş sayısı da eklenerek çalışmada farklı sonuçlara ulaşılabilir. Literatür tarandığında aile gelir düzeyi ile uzaktan eğitim ve akademik öz-yeterlik arasında ilişkiye dair herhangi bir çalışmaya rastlanmamıştır. Bu eksikliği gidermek için bu değişken ile araştırma konusu üzerinde daha fazla çalışmalar yapılabilir. Her çalışmanın olduğu gibi bu çalışmanın da bazı sınırlılıkları bulunmaktadır. Bu araştırma sadece Çanakkale Onsekiz Mart Üniversitesi’nde öğrenim gören öğrencilerin katılımı ile araştırma çalışmasında kullanılan ölçeklerle elde edilen verilerden oluşmaktadır. Aynı araştırma özel üniversitede ya da meslek yüksek okullarında okuyan öğrencilerle de tekrarlanabilir. Araştırma nicel 
araştırma yöntemleri kullanılarak gerçekleştirilmiştir. Elde edilen bulgular, nitel araştırma tekniklerinden yararlanılarak derinlemesine incelenebilir. 


\section{KAYNAKÇA}

Ağır, F. (2007) "Üniversite Öğrencilerinin Uzaktan Eğitim Dersine Karşı Tutumlarının İncelenmesi” Gaziantep Üniversitesi Spor Bilimleri Dergisi Cilt 4 Sayı 3 Y11 2019, 345-355.

Akkuş, N. (2008) "Yaşam Boyu Öğrenme Becerilerinin Göstergesi Olarak 2006 Pısa Sonuçlarının Türkiye Açısından Değerlendirilmesi” Sakarya University Journal of Education Cilt: 2 Sayı: 3 Y11 2012, 34-48.

Aktaş, G. (2013) "Feminist Söylemler Bağlamında Kadın Kimliği: Erkek Egemen Bir Toplumda Kadın Olmak” Edebiyat Fakültesi Dergisi Cilt 30 Sayı 1 Y1l 2013, 5470.

Albayrak, E., Yazıcı; H. ve Reisoğlu, S. (2016) "Üniversite Öğrencilerinde Kişilik Özellikleri, Akademik Öz-Yeterlik, Akademik Kontrol Odağ 1 ve Akademik Erteleme" Mehmet Akif Ersoy Üniversitesi Eğitim Fakültesi Dergisi Sayı 38 Y11 2016, 90-102.

Alkan, C. (1987) “Ankara Üniversitesi Uzaktan Eğitim Programına Katılan Öğrencilerin Akademik Başarılarını Etkileyen Faktörler” Yüksek Lisans Tezi Y11 2011, 14 Ankara

Anderson, P. (2007) "Web 2.0 Nedir?: Fikirler, Teknolojiler ve Eğitime Etkileri” JISC Technology and Standards Watch Y11 2007, 1-64.

Aydoğan, D.; ve Özbay, Y. (2012) “Akademik Erteleme Davranışının Benlik Saygısı, Durumluluk Kaygı, Öz-yeterlik Açısından Açıklanabilirliğinin İncelenmesi” Pegem Eğitim ve Öğretim Dergisi Cilt 2 Sayı 3 Y11 2012

Bandura, A. (1993) “Uzaktan Eğitim Öğrencilerinin Çevrim İçi Teknolojilere Yönelik Özyeterlik Algılarının İncelenmesi” Celal Bayar Üniversitesi Sosyal Bilimler Dergisi Y11 2020, 33-46.

Bandura, A. (1993) "Uzaktan Eğitim Öğrencilerinin Çevrim İçi Teknolojilere Yönelik Özyeterlik Algılarının İncelenmesi” Celal Bayar Üniversitesi Sosyal Bilimler Dergisi Y11 2020, 33-46.

Bandura, A. (1997) “Öz yeterlik: Kontrol uygulaması. New York: Freeman” Öz-yeterlik Araştırmalarında Güncel Yönler Yıll 1999, 157-167.

Bandura, A. (1997) “Öz yeterlik: Kontrol uygulaması. New York: Freeman” Öz-yeterlik Araştırmalarında Güncel Yönler Y1l 1999 ,157-167.

Başaran, I. E. (1978) Eğitime Giriş, Bimaş Matbaacılık, Y1l 1978, Ankara.

Bayram, M.; Peker, A.T.; Vural, M. ve Aka, S.T. (2019) "Üniversite Öğrencilerinin Uzaktan Eğitim Dersine Karşı Tutumlarının İncelenmesi” Gaziantep Üniversitesi Spor Bilimleri Dergisi Cilt 4 Say1 3 Year 2019 330- 345. 
Bayram vd., (2019) "Üniversite Öğrencilerinin Uzaktan Eğitim Dersine Karş1 Tutumlarının İncelenmesi” Gaziantep Üniversitesi Spor Bilimleri Dergisi Cilt 4 Say1 3 Year 2019 330- 345

Bayram vd., (2019) “Üniversite Öğrencilerinin Uzaktan Eğitim Dersine Karş1 Tutumlarının İncelenmesi” Gaziantep Üniversitesi Spor Bilimleri Dergisi Cilt 4 Say1 3 Year 2019 330- 345.

Block, J.; ve Robins, R.W. (1993) "İngilizce Öğrencilerinin Öz Benlik Saygısı ve Akademik Öz-Yeterlik Algılarının Bazı Değişkenler Açısından İncelenmesi”" Sosyal Bilimler Enstitüsü Dergisi 136.

Bozkurt, A. (2017) “Türkiye'de uzaktan eğitimin dünü, bugünü ve yarını” Açıköğretim Uygulamaları ve Araştırmaları Dergisi Cilt 3 Sayı 2 Yı1 2017, 85-124.

Chemers, HU, Garcia, (2001); Kamin, (2009); Margolis, McCabe, (2004) “Akademik Özyeterlik : Olumlu ve Olumsuz Duygulanım Yordayıcı Rolü” Eğitim ve Öğretim Araştırmaları Dergisi Cilt 3 Sayı 2 Y11 $2014,96$.

Chun; ve Choi (2005) “Akademik Öz-yeterlik ile Öğretmen Öz-yeterlikleri Arasındaki İlişki” İnternational Journal of Human Sciences Y1l 2013 10: 1 , 1169.

Çağır, G. (2010) "Lise ve üniversite öğrencilerinin problemli internet kullanım düzeyleri ile algılanan esenlik halleri ve yalnızlık düzeyleri arasındaki ilişki" Balıkesir Üniversitesi Sosyal Bilimler Enstitüsü Eğitim Bilimleri Anabilim Dalı Y11 2010, $10-90$.

Çubukçu Z.; ve Girmen P. (2007) "Öğretmen Adaylarının Sosyal Öz-yeterlik Algıların Belirlenmesi” Eskişehir Osmangazi Üniversitesi Sosyal Bilimler Dergisi Cilt 8 Sayı 1 Y11 2007 3-18.

Dündar, Karaca; ve Yapıcı, Y. (2013) "Pedagojik Formasyon Öğrencilerinin Öğretmenlik Mesleğine Yönelik Öz-yeterlik İnançları ile Tutumları Arasındaki İlişki”" Kastamonu Eğitim Dergisi Cilt 25 Y1l 2017, 1393.

Düzakın, E.; ve Yalçınkaya, S. (2008) "Uzaktan Eğitim Kurumlarından 'transactional distance'ın Türkçeleştirilmesi” Açıköğretim Uygulamaları ve Araştırmaları Dergisi Sayı 3 Cilt 2 Y11 2016, 75-87.

Etlioğlu M.; ve Tekin M. (2020) "Elektronik Öğrenmede Öğrenci Tutum ve Akademik Başarı Arasındaki İlişkide Öğrenci Merak ve Kaygısının Aracılık Rolü” Selçuk Üniversitesi Sosyal Bilimler Enstitü Dergisi Y1l 2020, 34-48.

Horzum, M.B. (2003) “Öğretim elemanlarının internet destekli eğitime yönelik düşünceleri : Sakarya Üniversitesi örneği” Sakarya Üniversitesi Sosyal Bilimler Enstitüsü Y11 2003

Ilgaz, H. (2008) "Uzaktan eğitimde teknoloji kabulünün ve topluluk hissinin öğrenen memnuniyetine katkısı (Yüksek lisans tezi). Hacettepe Üniversitesi Fen Bilimleri Enstitüsü, Y11 2008, 75-76, Ankara. 
İnceoğlu, M. (2000) Tutum Algı İletişim. İmaj Yayıncılık Y11 2000 Ankara.

İşman, A. (2009) "The diffusion of Distance Education in Turkish Higher Education.Educational” Technology Research \& Development, Cilt 45 Sayı 2, 11 65.

Kandemir, M. (2010) “Akademik erteleme davranışını açıklayıcı bir model (Yüksek lisans tezi). Gazi Üniversitesi Eğitim Bilimleri Enstitüsü, Yı1 2010, 46, Ankara.

Karaduman, A. (2015) "Üniversite Öğrencilerinin Yaşam Boyu Öğrenme Eğilimleri ile Öz-yeterlik Algıları Arasındaki İlişki” Y1l 2015 Bartın.

Karaman, S.; ve Karabey, S. (2020) “Uzaktan Öğretimde Canlı Ders Uygulama İlkeleri ve Örnekleri; Bölüm 1: Canlı Derslerin Genel Özellikleri ve İşleyişiı” Atatürk Üniversitesi Yayınevi Y11 2020 Erzurum.

Kaşarc1, İ.; Yiğit, R.; ve Yılmaz, E. (2012) "İlköğretim öğrencilerinin öz-yeterlik düzeylerinin akademik başarı ve bazı değişkenler açısından incelenmesi” Mehmet Akif Ersoy Üniversitesi Eğitim Fakültesi Dergisi Y1l 2012, Sayı 23, 371 - 388.

Kaya, Z.; ve Önder, H.H (2002) "Üniversite Öğrencilerinin Uzaktan Eğitim Dersine Karş1 Tutumlarının İncelenmesi” Gaziantep Ünniversitesi Spor Bilimleri Dergisi Cilt: 4 Say1: 3 Y11 2019, 330-345.

Kaya, Z. (2002) “Uzaktan Eğitim: Uzaktan Eğitim Gereksinimi” Pegem Akademi Yayınlar1 Y11 2002, 15-281.

Liaw, S.S (2007) "Surveying Instructor and Learner Attitudes Toward E-learning" Computers \& Education Year 2007, 1066-1080.

Lorsbach A.; ve Jinks J. (1999) "Öz-yeterlik Kuramı ve Öğrenme Ortamı Araştırması" Öğrenme Ortamları Araştırması Y11 1999, 157-167.

Marayam; Ghasemzadeh; ve Soleimani, (2011) “İngilizce öğrencilerinin öz benlik saygıs1 ve akademik öz-yeterlik algılarının bazı değişkenler açısından incelenmesi” Sosyal Bilimler Enstitü Dergisi Y1l 2011, 139.

Nahm, ES.; ve Resnick, B. (2008) "Uzaktan Eğitim Öğrencilerinin Çevrim İçi Teknolojilere Yönelik Öz-yeterlik Algılarının İncelenmesi” Celal Bayar Üniversitesi Sosyal Bilimler Dergisi Y11 2020 , 33-46.

Oğuz, A. (2009), Choi (2005), TAŞKIN, HACIÖMEROĞLU (2010) "Sınıf Öğretmeni Adaylarının Akademik Öz-yeterlik İnançları” Dumlupınar üniversitesi Y1l 2009, 22.

Önür, H. (2013) Gelir Düzeyinin Eğitim İmkanlarından Yararlanma Düzeyine Etkisi Süleyman Demirel Üniversitesi Sosyal Bilimler Enstitüsü Dergisi Y1l 2013, Say1 $18259-275$ 
Özdoğan, A.Ç.; ve Berkant, H.G. (2020) “Covid-19 Salgını Sırasında Paydaşların Uzaktan Eğitime İlişkin Görüşlerinin İncelenmesi” Milli Eğitim Y11 2020, 13-43.

Özdoğan, A.Ç.; ve Berkant, H.G. (2020) “Covid-19 Salgını Sırasında Paydaşların Uzaktan Eğitime İlişkin Görüşlerinin İncelenmesi” Milli Eğitim Y11 2020, 15-39.

Özdoğan, A.Ç.; ve Berkant, H.G. (2020) “Covid-19 Salgını Sırasında Paydaşların Uzaktan Eğitime İlişkin Görüşlerinin İncelenmesi” Milli Eğitim Y11 2020, 15-39.

Özgenel, M.; ve Deniz, A. (2020) “Öğretmenlik Mesleğine İlişkin Tutum ile Akademik Güdülenme ve Akademik Öz-yeterlik Arasındaki İlişki :Öğretmen Adayları Üzerine Bir İnceleme” Üniversite Araştırmaları Dergisi Cilt: 3 Sayı: 3 Y11 2020 , 138 .

Özgüven, İ.E. (1974) "Akademik Başarının Yordayıcısı Olarak Gündelik Sıkıntılar ve Sosyal Destek” Hacettepe Üniversitesi Eğitim Fakültesi Dergisi Y1l 2006 ,258-267.

Pajares, F. (1996) "Akademik Öz-yeterlik ile Akademik Başarı Arasındaki İlişskide Sınav Kaygısı ve Akademik Motivasyonun Aracı Rolü’ Y11 2019 , 244.

Pajares, F. (1996) “Akademik Öz-yeterlik ile Akademik Başarı Arasındaki İlişkide Sınav Kaygısı ve Akademik Motivasyonun Arac1 Rolü” Y11 2019, 244.

Palloff, R.M; ve Pratt, K. (1999) "Learning in An Online Distance Education Course: Experiences of Three İnternational Students" İnternational Review of Resarch in Open and Distance Learning Volume: 11 Number: 1 Year 2010 ,17-36.

Poyrazlı vd., (2002) "Akademik Öz yeterlik : Olumlu ve Olumsuz Duygulanım Yordayıc1 Rolü” Eğitim ve Öğretim Araştırmaları Dergisi Cilt: 3 Sayı: 2 Yı1 2014, 244.

Poyrazlı vd., (2002)“Akademik Öz yeterlik:Olumlu ve Olumsuz Duygulanım Yordayıcı Rolü” Eğitim ve Öğretim Araştırmaları Dergisi Cilt: 3 Sayı: 2 Y11 2014, 244.

Sakız, G. (2013)“Başarıda Anahtar Kelime :Öz -Yeterlik” Eğitim Fakültesi Dergisi Yı1 2013, 185-209.

Saracaloğlu, A. S.; Karademir, Ç.A.; Dursun, F.; Altın, M.; ve Üstündağ, N. (2013) "Sınıf Öğretmeni Adaylarının Öz-düzenleyici Öğrenme Becerilerinin Akademik Özyeterlik Akademik Kontrol Odağı ve Akademik Başarıları ile İlişkisi”, 385.

Satıcı, S.; ve Akın, A. (2013) "Öznel Mutluluk Ölçeği: Geçerlik ve Güvenirlik Çalışması” Sakarya Üniversitesi Eğitim Fakültesi Dergisi Sayı: 21 Y11 2013, 65-77.

Schuzlt, M. ve Schuzlt, M. (2007) "Öz-yeterlik, Yaşam Anlamı ve Yaşam Bağlılığı Kavramları Üzerine Bir İnceleme" Üsküdar Üniversitesi İletişim Fakültesi Akademik Dergisi Y1l 2018, 78-89. 
Senemoğlu, N. (2003) "Elektronik Öğrenmede Öğrenci Tutum ve Akademik Başarı Arasındaki İlişkide Öğrenci Merak ve Kaygısının Aracılık Rolü” Selçuk Üniversitesi Sosyal Bilimler Enstitüsü Dergisi Sayı: 43 Y11 2020, 374-48.

Shea, P.; ve Bidjerano, T. (2009) "Çevrimiçi Eğitimde "Epistemik Katılımı" ve "Bilişsel Varlığı" Teşvik Etmek İçin Teorik Bir Çerçeve Olarak Sorgulama Topluluğu" Computers and Education Volume 52 Issue 3 Year 2009 , 543-553.

Shen, B. vd., (2013) "Uzaktan Eğitim Öğrencilerinin Çevrim İçi Teknolojilere Yönelik Öz-yeterlik Algılarının İncelenmesi” Celal Bayar Üniversitesi Sosyal Bilimler Dergisi Y11 2020, 33-46.

Spielberger, C.D. (1972) "Ruh Hali Durumlarının Profilinin Gözden Geçirilmesi” APA PsycMakaleleri: Dergi Makalesi Y11 2021, 387-388.

Spinath, B. (2012) “Akademik Öz yeterlik : Olumlu ve Olumsuz Duygulanım Yordayıc1 Rolü” Eğitim ve Öğretim Araştırmaları Dergisi Cilt: 3 Sayı: 2 Yı1 2014, 244.

Steinmayr, A. (2016) “Akademik Öz-yeterlik ile Akademik Başarı Arasındaki İlişside Sınav Kaygısı ve Akademik Motivasyonun Aracı Rolü” Y11 2019 , 244.

Şenel, S.; ve Kutlu, Ö. (2015) “Ankara Üniversitesi Uzaktan Eğitim Programına Katılan Öğrencilerin Akademik Başarılarını Yordayan Faktörler” Eğitimde ve Psikolojide Ölçme ve Değerlendirme Dergisi Y11 2015, 177-193.

Tabachnick, B.G.; ve Fidell, L.S. (2013) Using Multivariate Statistics (sixth ed.) Pearson, Y11 2013, Boston.

Tabachnick, B.G.; ve Fidell, L.S. (2013) Using Multivariate Statistics (sixth ed.) Pearson, Y1l 2013, Boston.

Torres, J.B.; ve Solberg, V.S. (2001) “Akademik Öz yeterlik : Olumlu ve Olumsuz Duygulanım Yordayıcı Rolü” Eğitim ve Öğretim Araştırmaları Dergisi Cilt: 3 Say1: 2 Y11 $2014,96$.

Tosun N.; ve Hatipoğlu, N. (2009) "İnternete Dayalı Uzaktan Eğitim Sisteminde Sınav Modülü" 9th international educational technology conference, 289.

Ummanel, A. (2010) "Yaşam Becerileri” İstanbul Üniversitesi Açık ve Uzaktan Eğitim Fakültesi Y11 2010, 201-211.

Usher, E.L; ve Pajares, F. (2006) “Akademik Öz-yeterlik ile Akademik Başarı Arasındaki İlişkide Sınav Kaygısı ve Akademik Motivasyonun Aracı Rolü” Y11 2019, 245246.

Usher, E.L; ve Pajares, F. (2008) “Akademik Öz-yeterlik ile Akademik Başarı Arasındaki İlişkide Sınav Kaygısı ve Akademik Motivasyonun Aracı Rolü” Y11 2019, 245246.

Uşun, S. (2006) "Uzaktan Eğitim Öğrencilerinin Memnuniyet Algıları Üzerine Bir 
Araştırma” Sosyal Bilimler Dergisi Cilt: 3 Sayı: 1 Y1l 2013, 64-75.

Varol, N.; ve Çoban, N. (2013) "Uzaktan Eğitimin Tarihsel Gelişimi ve Türkiye'deki Durumu” Marmara İletişim Dergisi Sayı: 21 Y11 2014, 73-94.

Woo, Y.; ve Reeves, T.C. (2007) "Öğrenmede Sohbete Katılım ve Ödev Göndermenin Akademik Başarıya Etkisi” 9th İnternational Educational Technology Comference

Yalın, (2007) "Üniversite Öğrencilerinin Uzaktan Eğitim Dersine Karşı Tutumlarının İncelenmesi” Gaziantep Üniversitesi Spor Bilimleri Dergisi Cilt: 4 Sayı :3 Year 2019, 330- 345.

Zimmerman, B.J.; Bandura A.; ve Martinezpons, M. (1992) "Akademik Öz yeterlik : Olumlu ve Olumsuz Duygulanım Yordayıcı Rolü” Eğitim ve Öğretim Araştırmaları Dergisi Cilt: 3 Sayı: 2 Y11 2014, 96.

Zimmerman, B.J. (1995) “Öğretmen Adaylarının Sosyal Öz-yeterlik Algıların Belirlenmesi” Eskişehir Osmangazi Üniversitesi Sosyal Bilimler Dergisi, 96.

Zimmerman, B.J.; ve Kitsantas, A. (2005) “Akademik Öz-yeterlik : Olumlu ve Olumsuz Duygulanım Yordayıcı Rolü” Eğitim ve Öğretim Araştırmaları Dergisi Cilt: 3 Say1 2 Y11 2014, 96. 


\section{Relations Between Distance Education Attitudes And Academic Self-Sufficiency In University Students}

\section{EXTENTED SUMMARY}

\section{RESEARCH PURPOSE}

The aim of the study is to examine the relationship between the attitudes of university students studying at Çanakkale Onsekiz Mart University towards distance education and their academic self-efficacy. For this purpose, the relationship between socio-demographic variables and dependent variables (attitudes towards distance education and academic self-efficacy towards courses) was examined, and it was investigated whether there was a difference between the groups formed on the basis of sociodemographic variables in terms of dependent variable levels. This research will reveal how distance education and attitudes towards distance education affect students' motivation compared to face-toface education, and students' self-efficacy perceptions based on their motivation level.

\section{RESEARCH QUESTIONS}

The research questions were determined as follows; Is there a significant relationship between female and male university students in terms of attitudes towards distance education and academic selfefficacy levels? Is there a significant relationship between the maternal education levels of university students in terms of attitudes towards distance education and academic self-efficacy levels? Is there a significant relationship between university students' liking for school in terms of attitudes towards distance education and academic self-efficacy levels? Is there a significant relationship between university students' liking the department in terms of attitudes towards distance education and academic self-efficacy level? Is there a significant relationship between the computer use levels of university students in terms of attitudes towards distance education and academic self-efficacy levels?

\section{INTRODUCTION}

People acquire the knowledge and skills they need in general subjects such as adapting to the environments they live in, communicating, transferring knowledge and experiences from the past to the next generations, and developing a lifestyle suitable for the period in which they live (Akkuş 2008: 12). The concept of communication, which started with a letter in ancient times, then leaves its place to the communication established in the practical and more accessible electronic environment, and in this way, the education system has to shape and develop itself for each generation. With the development of distance communication, a distance education system has been established in the education system in order to be more accessible both on behalf of teachers and on behalf of learners. 
On this basis, in cases where face-to-face education cannot be provided or with the distance education systems developed to support the education processes, learning opportunities independent of time and place can be offered (Kaya, 2002:18). Along with distance education, the attitudes of the students towards the course materials taught in the electronic environment are known by the student herself and the instructors, and the course contents and designs are made according to these situations (Karaman ve Karabey, 2020: 12). Distance education creates positive/negative effects on students in terms of academic motivation, self-confidence, self-efficacy, coping with problems, planning. The concept of self-efficacy, which also affects the distance education system, refers to the belief of individuals in their own capacity to show a certain performance (Bandura, 1997: 167). With the perception of selfefficacy, it is determined whether individuals will fulfill their responsibilities or not. Individuals with a high level of self-efficacy also have a high level of belief that they will be successful in the lessons (Schuzlt ve Schuzlt, 2007: 89). Individuals with low self-efficacy, on the other hand, quickly get bored with their responsibilities and are disappointed by not concluding their work. Self-efficacy has a feature that can be observed by external sources and interacted with external sources (Lorsbach ve Jinks, 1999: 167). Self-efficacy also has sub-branches within itself. One of them is academic selfefficacy. Academic self-efficacy refers to students' belief in their abilities for educational work (Satıc1, 2013: 77).

\section{METHODOLOGY}

The universe of the research was determined as Çanakkale Onsekiz Mart University students who continue their education in Çanakkale, and it was aimed to collect data from at least 331 students as a sample in the research. Relational screening model was used for the research. In order to collect data in the research, the Satisfaction in Distance Education Scale developed by Hale Ilgaz and consisting of 30 questions, the Personal Information Form prepared by the researcher for the participants, and the Academic Self-Efficacy Scale consisting of 19 questions developed by Mehmet Kandemir were used. The data obtained in the research were analyzed using the SPSS analysis program. During the analysis, product moment correlation analysis was used for relations between variables, independent groups ttest for two-group comparisons, one-way analysis of variance Anova test was used to evaluate binary variables, post-hoc tests were used to see if there was a significant difference between the groups and simple linear regression analysis was applied for predictive effects.

\section{RESULTS AND CONCLUSIONS}

As a result of the study, no significant difference was found between academic self-efficacy and student satisfaction in distance education scale and gender variable. There are parallel studies in the 
literature. In the studies conducted by Oğuz (2009), Choi (2005), Taşkın and Haciömeroğlu (2010), Usher and Pajares (2006), it is seen that there is no significant difference between gender and Academic Self-Efficacy and Satisfaction Scale scores. While there was a significant difference between academic self-efficacy and the variable of liking the department, it was determined that there was no significant difference with the student satisfaction scale scores in distance education. When the literature is examined, it is seen that there are studies supporting this situation. According to Yapıc1 and Yapıc1 (2013: 1393), it is seen that students studying in the teaching department generally have a positive attitude towards their departments by loving their departments. While there was a significant difference between academic self-efficacy and the variable of liking the university, it was determined that there was no significant difference with the student satisfaction scale scores in distance education. When the literature is examined, it is seen that there are studies supporting this situation. According to the results obtained from the research of Özgenel and Deniz (2020: 138), the positive attitude of the education faculty students towards the department and the university they are studying can be associated with their commitment to their profession. According to the general findings, it was concluded that students' attitudes towards their profession and academic motivation significantly predicted their academic self-efficacy. There was no significant difference between the student satisfaction scale scores in distance education and the part of liking the university. When we look at the literature, there are no studies that reach a definite conclusion on this subject. While there was a significant difference between academic self-efficacy and family income level, there was no significant difference between student satisfaction scale scores in distance education. It has been determined that academic self-efficacy and satisfaction scale scores, both academic self-efficacy scale scores and student satisfaction scale scores in distance education show a significant difference according to the computer usage level variable. When the literature is examined, it is seen that there are other studies supporting this result. According to the research of Çağır (2010: 90), the fact that new university students do not have difficulty in using the internet may be thanks to the efforts to spend more time with friends in order to create a rich social environment with the changing needs of university life and adapting to the new social environment.

The relationship between attitudes towards distance education and academic self-efficacy is predicted significantly. When evaluated in general, there is a significant relationship between attitudes towards distance education and academic self-efficacy (Etlioğlu \& Tekin, 2020: 48). Based on the results of the research, suggestions for new research and practitioners are listed below: In this study, variables were considered as gender, family income, mother's education level, father's education level, computer usage level, liking the university and liking the department. Different results can be obtained in the 
study by expanding the variables and adding age, marital status and number of siblings. When the literature was searched in the research, no study was found on the relationship between family income level and distance education and academic self-efficacy. In order to eliminate this deficiency, more studies can be done on the research subject with this variable. The scale of student satisfaction in distance education, which is one of the scales in the research, can be changed as a distance education attitude scale and its relationship with academic self-efficacy can be examined. 